\title{
Impact of Tailings on Surrounding Streams at a Mining Area in Sierra Leone
}

\author{
Ishmail Sheriff ${ }^{1, *}$, Eldred Tunde Taylor ${ }^{1}$, Alusine Bai Kamara ${ }^{1}$, Abdul Sannoh ${ }^{2}$ \\ ${ }^{1}$ Institute of Environmental Management and Quality Control, Njala University, Njala, Sierra Leone \\ ${ }^{2}$ United Nation Development Program, Global Environment Facility/Small Grant Program, Freetown, Sierra Leone
}

\section{Email addresses:}

etaylor@njala.edu.sl (E. T. Taylor),s.ishmail@rocketmail.com(I. Sheriff)

${ }^{*}$ Corresponding author

\section{To cite this article:}

Ishmail Sheriff, Eldred Tunde Taylor, Alusine Bai Kamara, Abdul Sannoh. Impact of Tailings on Surrounding Streams at a Mining Area in Sierra Leone. Earth Sciences. Vol. 7, No. 5, 2018, pp. 202-208. doi: 10.11648/j.earth.20180705.11

Received: July 18, 2018; Accepted: August 8, 2018; Published: September 6, 2018

\begin{abstract}
Access to clean water and sanitation is the centerpiece of Africa water vision 2025 and Goal six (6) of the 2030 UN agenda for Sustainable Development. Considering the current national WASH regulatory structures in Sierra Leone, meeting these targets enshrined in the policy documents would be a critical challenge for the government. The overarching objectives sought by the study were to determine the available composition of physio-chemical parameters and evaluate impact of mine tailings on nearby water bodies within the operational areas of Sierra Rutile Mining Company Limited. Twenty-four (24) water samples obtained from six (6) streams were tested for seventeen (17) physical and chemical parameters. About $30 \%$ of the indicators were noted to be above the permissible limit of water quality standard in almost all of the sampling sites. A pattern of decrease concentration downstream for $\mathrm{Zn}, \mathrm{Pb}$ and $\mathrm{Cu}$ was observed but those at the tailing points were noted otherwise. The results revealed that mining activities have to an extent negative impact on the local water sources. Consequently, certain indicators were considered to be of public health concern considering their baseline levels. It would be necessary for the company to examine the mechanism of discharge of tailings and strengthen the environmental surveillance within its concessionary areas to enhance sustainability with the ultimate goal to improve environmental performance.
\end{abstract}

Keywords: Tailing, Water Quality, Physico-Chemical, Impact, Chemicals

\section{Introduction}

Ensuring availability, accessibility and sustainable management of water has been the centrality of multiple policy forums [1]. In spite of this, it has been recently reported that 844 million people still have no access to a basic drinking water facility and 159 million of them are directly dependent on surface water, $58 \%$ of which are in sub-Saharan Africa [2]. It is likely that the current estimate reported by WHO and UNICEF would increase over time given the trends in global population growth rate. However, the issue of water quality is more severe in the areas where excessive mining operations and related processes are present [3]. Report from studies have shown that various forms of contaminants are continually introduced into water bodies mainly due to mining activities [4-6]. This consequently would have the propensity of severe ecotoxicological threats to human and other living organisms that rely on water bodies $[7,8]$.

There is a wide array of studies on surface water quality in mining environments worldwide [8-13]. Also, in Africa several studies on surface water in mining areas were reported [14-16]. But in Sierra Leone, studies on water quality have focused on different aspects of water. For example, a study on the physical and biological parameters of an entire water supply network was reported [17]. Another study have investigated the quality of 60 groundwater from wells [18]; while an earlier study that looked at the public health risk related to water quality [19] was reported. One of the few studies identified in the literature relating to water quality from mining environment in Sierra Leone was from groundwater sources [20]. 
Notably, there is no information on surface water quality particularly in mined out areas that has been reported in Sierra Leone to the best of the authors' knowledge. Against such a backdrop, this study attempt to assess the impact of tailings from mining activities on streams; measure physiochemical parameters and compare the levels with WHO guideline 2011; examine degree of variation in concentration between the background site and all other sites to draw conclusion on downstream impact. Finding of this study would be very instrumental to decision makers and key stakeholders.

\section{Materials and Method}

\subsection{Description of Study Area}

Sierra Rutile Company Limited is a mineral sands company operating in Moyamba and Bonthe Districts in the Southern Province of Sierra Leone. The company's area of operation which is also the study area is politically divided into four chiefdoms: Upper Banta Chiefdom, Lower Banta Chiefdom, Imperi Chiefdom and Jong Chiefdom respectively from which the mines are located as represented in Figure 1. The most important town in the study area is Moriba town. Details of its physical and Climatic features, geology and socioeconomic characteristics has been described in an earlier study [20].
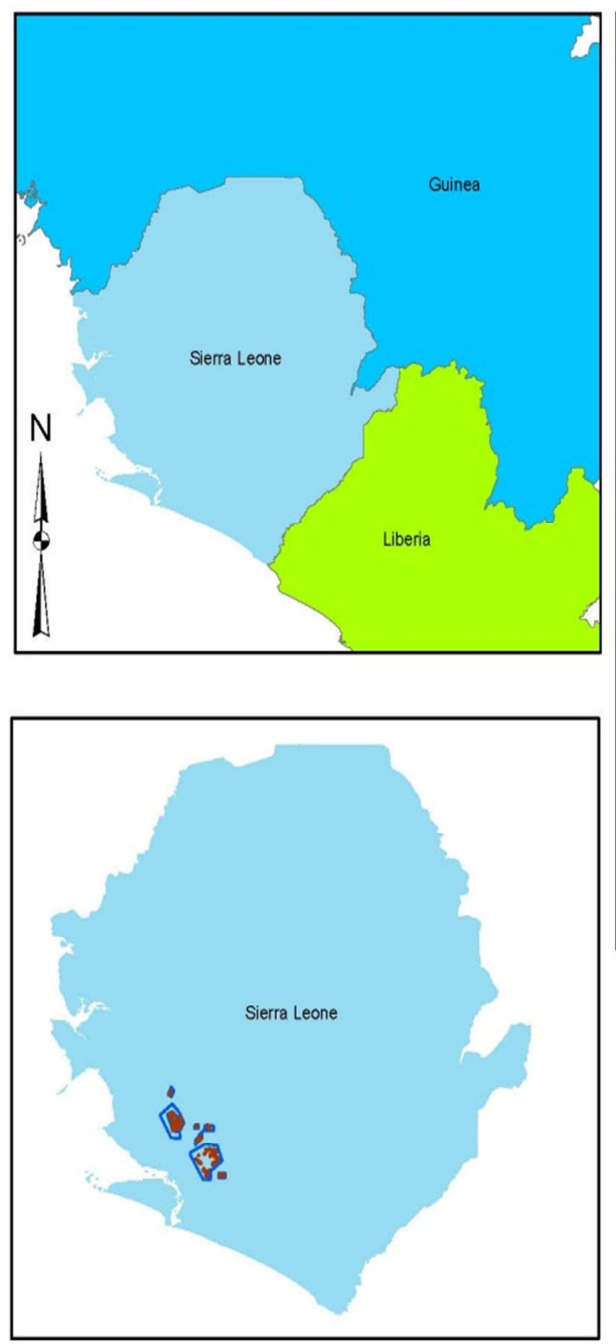

\subsection{Description of Study Sites}

The study sites were coded as Gondama Stream (GS), Dry mill tailings (DMT) stream, Gangama Dry Mining Tailings (GDMT) stream, Lanti Dry Mining Tailings (LDMT) pond, Dredge Tailings (DT) stream, and Wet Plant Tailings (WPT) Stream; in that order.

Gondama Stream is far away from the tailings and there
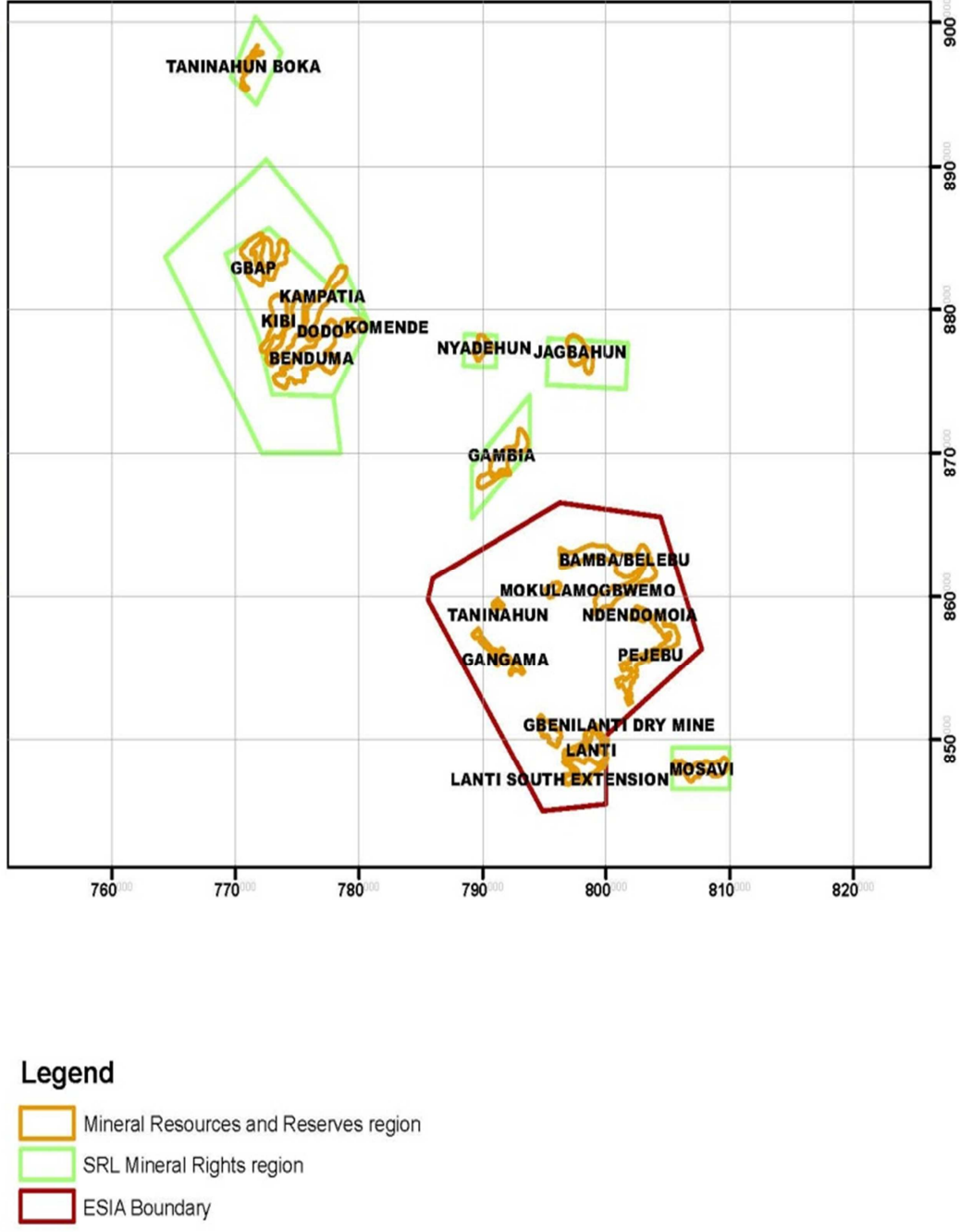

Figure 1. Location of Study Area.

are no reported mining related activities in the area. It passes through a village that abounds in rich vegetation. GS therefore provides excellent conditions for a background site for comparing downstream impact of tailings in the area based on the principle of the distance from mining regions. Inhabitant in this area practiced farming and fishing activities. Situated in the south end of the main plant is the DMT stream which is approximately three miles. It drain two 
villages characterized primarily by hilly landscape. The activities around the stream are same as in GS. The GDMT stream runs parallel to and within the Gangama dry mining plant. The stream is about two miles long stream and has three villages along it course with steep slope topography. The LDMT stream which is about half a mile lies in close proximity to Lanti dry mining fleet which is located adjacent to the concentrator plant. Likewise, GDMT, the dominant topography along the LDMT stream is primarily steep slopes. There are two villages along the course of the stream. The DT stream flows north-west to the processing plant which lie close to the dredge. The stream is about two miles long. The WPT stream is located adjacent to the wet plant, with a length of about three miles. The dominant physical features are hills and three villages are found along its path of flow.

\subsection{Water Sampling Procedures}

Field work was carried out from January $24^{\text {th }}$ to February $7^{\text {th }}$ 2018. Water samples were collected at four sites from each location using $500 \mathrm{~mL}$ high density polyethyleneterephthalate (PET) bottles. Each plastic bottle was thoroughly inspected to ascertain that it was not visibly contaminated, leaking or damage. A rope was tied at the top of the plastic bottles to collect samples at a depth of approximately $20 \mathrm{~cm}$ below the water surface. Each plastic bottle was pre-cleaned, and properly rinsed thrice with the water to be sampled prior to filling with the actual sample. This was done to avoid nonconformities in the samples. Each plastic bottle was tightly recapped with the screw cover. Water samples were collected from four sites per location (i.e. Upstream, at the tailings, at a village and downstream) in order to be able to assess concentration trends in each of the locations. Twenty-four water samples were collected in total and each plastic bottle was legibly labelled using an insoluble ink with sufficient information on coded identifier (i.e. location and sampling site), and date of collection so as to meet the samples acceptance criteria of the laboratory. Collected samples were temporarily stored in a cooler containing ice packs for indicators to be measured in the Lab. Subsequently, samples were then transported to the Sierra Rutile Limited Quality Laboratory and were preserved in refrigerator within 24-hours period after collection before chemical analyses. Sample were accompanied by test request (requisition) indicating which investigations are required.

Both in-situ and ex-situ analytical techniques were used to test for the various physical and chemical parameters respectively. The physical indicators mentioned in the following list: $\mathrm{pH}$, Temperature, turbidity, electrical conductivity and total dissolved solids were measured on site using a portable combined Accumet AC85 Fischer scientific $\mathrm{pH} /$ temperature/ conductivity meter. The instrument was calibrated before and during sampling in accordance with directives by the Manufacturer.

For ex-situ analysis, water samples were tested for chemical indicators at the Sierra Rutile Limited Quality Laboratory within 24 hours of sample collection. The following chemical indicators Chloride, Fluoride, Free iron,
Copper, Phosphate, Magnesium, Aluminium, Ammonia, Nitrate, Calcium hardness, Potassium, Lead and Zinc were analyzed using Wagtech Potalab Photometer 9500 (model ECOSENSE). To ensure the veracity of the result produced by the laboratory, the Standard Operating Procedures (SOP) for chemical analysis were strictly followed. Details of this analytical procedures were being reported earlier [20].

\subsection{Data Analyses}

The study design was quantitative in nature hence data were subjected to descriptive statistics. All statistical analyses were conducted using Microsoft Excel 2016. The mean and standard deviation values of the various locations were used to describe the concentration trend of the indicators measured. T-test was used to compare concentrations for parameters between locations. Significant variation ( $p$ value) in mean values was considered to be at $\mathrm{p}<0.05$ from which all statistical interpretations were made. The values of measured parameters were compared with Physical and chemical guideline standards of WHO (2011) for drinking water quality. Results for each indicator among locations were also compared with background site to draw conclusion on concentration trends of tailings downstream.

\section{Results and Discussion}

The summary statistics of the physio-chemical parameters in the study area are given in Tables 1 and 2 respectively. Descriptive statistics was used to compare the mean values of measured parameters with World Health Organization (WHO) water quality guidelines 2011 where applicable as presented in Table 3.

From Table 1, the results show that there is no significant variation in mean temperature values across sampling locations. The temperature values recorded for all the sampling locations in this study is firmly in line with those obtained for one of the investigated lakes in a previous study on Impact of coal mining on water quality in Brazil [13] and another study of surface water from major mining areas in Ghana [16] even though the mean values of the latter were slightly above those recorded in this current study. However, the temperature values reported in this work are in sharp contrast with those determined for water values in a tin mining area in Malaysia [21]. The aggregate $\mathrm{pH}$ values of the sampling site from four locations indicate acidity, with the strongest average concentration being 4.6 at the dredge tailing. Most sampling sites across tailings areas showed a high concentration of acidity in the study area. Acid generation is the main issue related to pollution from mining activities [22]. The high $\mathrm{pH}$ values ranging between 3.2 - 4.6 has been attributed to pyrite oxidation in the vicinity of a mining site [11]. However, the high acidic properties in three of the locations sampled in this study shared similar characteristics with an assessment of Surface Water Quality of a gold mining area in eastern Cameroon [14] even though the study design was slightly different. 
Table 1. Sites summary statistic of results of physical parameters.

\begin{tabular}{|c|c|c|c|c|c|c|}
\hline Site Name & & Temp. $\left({ }^{\circ} \mathrm{C}\right)$ & $p H$ & Turb (NTU) & $E C(\mu \mathrm{s} / \mathrm{cm})$ & $T D S(p p m)$ \\
\hline \multirow{4}{*}{ GS $n=4$} & Avg. & 24.6 & 6.38 & 3.27 & 33.3 & 16.6 \\
\hline & Stdev & 1.09 & 0.5 & 0.31 & 2.33 & 1.16 \\
\hline & Max. & 26.1 & 6.79 & 3.57 & 36.7 & 18.3 \\
\hline & Min. & 23.5 & 5.65 & 2.88 & 31.6 & 15.8 \\
\hline \multirow{4}{*}{ DMT n=4 } & Avg. & 23.68 & 4.82 & 28.08 & 44.5 & 22.2 \\
\hline & Stdev & 0.31 & 0.72 & 1.27 & 0.14 & 0.08 \\
\hline & Max. & 24.1 & 5.68 & 28.9 & 44.6 & 22.3 \\
\hline & Min. & 23.4 & 4.03 & 26.2 & 44.3 & 22.1 \\
\hline \multirow{4}{*}{ GDMT $n=4$} & Avg. & 23.93 & 4.705 & 40.55 & 20.09 & 9.57 \\
\hline & Stdev & 0.64 & 0.51 & 9.03 & 14.40 & 8.10 \\
\hline & Max. & 24.6 & 5.16 & 49.6 & 41.6 & 21.7 \\
\hline & Min. & 23.1 & 4.02 & 28.9 & 11.55 & 5.09 \\
\hline \multirow{4}{*}{ LDMT $n=4$} & Avg. & 21.15 & 5.43 & 43.75 & 14.53 & 8.14 \\
\hline & Stdev & 1.3 & 0.39 & 10.95 & 1.94 & 1.9 \\
\hline & Max. & 22.5 & 5.86 & 58.6 & 16.9 & 10.9 \\
\hline & Min. & 19.6 & 5.02 & 32.4 & 12.5 & 6.84 \\
\hline \multirow{4}{*}{ DT $n=4$} & Avg. & 24.5 & 4.64 & 41.73 & 20.9 & 14.9 \\
\hline & Stdev & 0.66 & 0.32 & 5.62 & 1.12 & 1.09 \\
\hline & Max. & 25.2 & 4.96 & 49.8 & 22.1 & 16.3 \\
\hline & Min. & 23.6 & 4.24 & 36.8 & 19.8 & 13.9 \\
\hline \multirow{4}{*}{ WPT $n=4$} & Avg. & 23.45 & 4.71 & 36.48 & 23.15 & 23.7 \\
\hline & Stdev & 1.19 & 0.3 & 21.97 & 3.14 & 1.66 \\
\hline & Max. & 24.8 & 5.01 & 69.4 & 25.6 & 25.3 \\
\hline & Min. & 21.9 & 4.32 & 24.2 & 18.6 & 21.5 \\
\hline
\end{tabular}

Table 2. Sites summary statistic of results of chemical parameters.

\begin{tabular}{|c|c|c|c|c|c|c|c|c|c|c|c|c|c|}
\hline & & $\begin{array}{l}C l \\
(m g / L)\end{array}$ & $A l(m g / L)$ & $\begin{array}{l}\mathrm{NH3} \\
(\mathrm{mg} / \mathrm{L})\end{array}$ & $\begin{array}{l}\mathrm{Ca} \\
(\mathrm{mg} / \mathrm{L})\end{array}$ & $\begin{array}{l}C u \\
(m g / L)\end{array}$ & $\begin{array}{l}F \\
(m g / L)\end{array}$ & $\begin{array}{l}F e \\
(m g / L)\end{array}$ & $\begin{array}{l}M g \\
(m g / L)\end{array}$ & $\begin{array}{l}\mathrm{NO}_{3}^{-} \\
(\mathrm{mg} / \mathrm{L})\end{array}$ & $\begin{array}{l}k \\
(m g / L)\end{array}$ & $\begin{array}{l}P b \\
(m g / L)\end{array}$ & $\begin{array}{l}Z n \\
(m g / L)\end{array}$ \\
\hline \multirow{4}{*}{ GS n $=4$} & Avg. & 0.51 & 0.02 & N/D & N/D & 0.06 & N/D & 0.04 & 1.83 & N/D & 1.25 & 0.02 & 0.02 \\
\hline & Stdev & 0.06 & 0.01 & N/D & N/D & 0.01 & N/D & 0.01 & 0.24 & N/D & 0.13 & 0.01 & 0.01 \\
\hline & Max. & 0.58 & 0.03 & N/D & N/D & 0.07 & N/D & 0.05 & 2 & N/D & 1.4 & 0.04 & 0.01 \\
\hline & Min. & 0.45 & 0.01 & N/D & N/D & 0.04 & N/D & 0.02 & 1.5 & N/D & 1.1 & 0.01 & 0 \\
\hline \multirow{4}{*}{ DMT n=4 } & Avg. & 0.89 & 0.11 & 0.21 & 3.25 & 1.7 & N/D & 0.5 & 4.5 & 0.15 & 3.23 & 0.07 & 0.04 \\
\hline & Stdev & 0.33 & 0.02 & 0.41 & 2.22 & 0.19 & N/D & 0.48 & 2.65 & 0.03 & 0.26 & 0.05 & 0.04 \\
\hline & Max. & 1.26 & 0.14 & 0.82 & 6 & 1.96 & N/D & 1.2 & 8 & 0.19 & 3.6 & 0.13 & 0.09 \\
\hline & Min. & 0.46 & 0.09 & 0.01 & 1 & 1.5 & N/D & 0.12 & 2 & 0.11 & 3 & 0.02 & 0.01 \\
\hline \multirow{4}{*}{ GDMT $n=4$} & Avg. & 0.35 & 0.30 & 0.17 & 3.5 & 1.29 & 0.33 & 0.63 & 3.1 & 0.23 & 2.25 & 0.04 & 0.03 \\
\hline & Stdev & 0.08 & 0.36 & 0.16 & 3.11 & 0.84 & 0.25 & 0.4 & 2.39 & 0.10 & 1.17 & 0.04 & 0.03 \\
\hline & Max. & 0.46 & 0.83 & 0.4 & 7 & 1.98 & 0.6 & 1.2 & 6 & 0.32 & 3.6 & 0.1 & 0.07 \\
\hline & Min. & 0.3 & 0.03 & 0.06 & 0 & 0.06 & 0.01 & 0.3 & 0.6 & 0.14 & 1 & 0.01 & 0.01 \\
\hline \multirow{4}{*}{ LDMT $n=4$} & Avg. & 0.51 & 0.34 & 0.03 & 2.5 & 1 & 0.2 & 0.24 & 2.67 & 0.42 & 1.65 & 0.06 & 0.04 \\
\hline & Stdev & 0.09 & 0.40 & \#DIV/0! & 2.08 & 0.65 & \#DIV/0! & 0.21 & 2.08 & 0.16 & 0.93 & 0.05 & 0.04 \\
\hline & Max. & 0.63 & 0.93 & 0.03 & 5 & 1.86 & 0.2 & 0.5 & 5 & 0.63 & 2.8 & 0.13 & 0.1 \\
\hline & Min. & 0.42 & 0.1 & - & 0 & 0.4 & - & 0.04 & 1 & 0.26 & 0.6 & 0.02 & 0.01 \\
\hline \multirow{4}{*}{ DT $n=4$} & Avg. & 0.46 & 0.62 & 0.26 & 4.5 & 0.45 & N/D & 0.2 & 6.25 & 0.57 & 1.55 & 0.06 & 0.04 \\
\hline & Stdev & 0.12 & 0.48 & 0.22 & 2.65 & 0.25 & N/D & 0.2 & 4.99 & 0.3 & 0.93 & 0.04 & 0.03 \\
\hline & Max. & 0.55 & 1.21 & 0.56 & 8 & 0.8 & N/D & 0.5 & 11 & 0.97 & 2.7 & 0.11 & 0.09 \\
\hline & Min. & 0.29 & 0.05 & 0.09 & 2 & 0.2 & N/D & 0.1 & 1 & 0.26 & 0.5 & 0.02 & 0.01 \\
\hline \multirow{4}{*}{ WPT n=4 } & Avg. & 0.33 & 0.66 & 0.36 & 4.5 & 1.13 & N/D & 0.68 & 0.35 & 0.50 & 0.28 & 0.08 & 0.05 \\
\hline & Stdev & 0.22 & 0.43 & 0.24 & 3.32 & 0.39 & N/D & 0.64 & 0.21 & 0.28 & 0.17 & 0.06 & 0.05 \\
\hline & Max. & 0.63 & 1.26 & 0.69 & 9 & 1.58 & N/D & 1.6 & 0.6 & 0.86 & 0.5 & 0.16 & 0.12 \\
\hline & Min. & 0.12 & 0.3 & 0.12 & 2 & 0.65 & N/D & 0.2 & 0.1 & 0.19 & 0.1 & 0.01 & 0.02 \\
\hline
\end{tabular}

Table 3. Comparison of the mean values of Physiochemical indicators with the WHO guideline standard.

\begin{tabular}{|c|c|c|c|c|c|c|c|}
\hline \multirow{2}{*}{ PARAMETERS } & \multirow{2}{*}{$\begin{array}{l}\text { WHO } \\
\text { STANDARDS } 2011 \\
\end{array}$} & \multicolumn{6}{|c|}{ AVERAGE VALUES OF THE SAMPLING LOCATIONS } \\
\hline & & GS & DMT & GDMT & LDMT & DT & WPT \\
\hline Temp. $\left({ }^{\circ} \mathrm{C}\right)$ & - & 24.6 & 23.68 & 23.93 & 21.15 & 24.5 & 23.45 \\
\hline $\mathrm{pH}$ & $6.5-8.5$ & 6.38 & 4.82 & 4.71 & 5.43 & 4.64 & 4.71 \\
\hline Turb. (NTU) & 5 & 3.27 & 28.08 & 40.55 & 43.75 & 41.73 & 36.48 \\
\hline $\mathrm{EC}(\mu \mathrm{s} / \mathrm{cm})$ & 1400 & 33.3 & 44.5 & 20.09 & 14.53 & 20.9 & 23.15 \\
\hline TDS (ppm) & 1000 & 16.6 & 22.2 & 9.57 & 8.14 & 14.9 & 23.7 \\
\hline $\mathrm{Cl}^{-}(\mathrm{mg} / \mathrm{L})$ & 250 & 0.51 & 0.89 & 0.35 & 0.51 & 0.46 & 0.33 \\
\hline $\mathrm{Al}(\mathrm{mg} / \mathrm{L})$ & 0.10 & 0.02 & 0.11 & 0.30 & 0.34 & 0.62 & 0.66 \\
\hline
\end{tabular}




\begin{tabular}{llllllll}
\hline \multirow{2}{*}{ PARAMETERS } & WHO & \multicolumn{2}{l}{ AVERAGE VALUES OF THE SAMPLING LOCATIONS } & \multicolumn{1}{l}{ W } \\
\cline { 3 - 8 } & STANDARDS 2011 & GS & DMT & GDMT & LDMT & DT & WPT \\
\hline $\mathrm{NH}_{3}(\mathrm{mg} / \mathrm{L})$ & $1.5-35$ & $\mathrm{~N} / \mathrm{D}$ & 0.21 & 0.17 & 0.03 & 0.26 & 0.36 \\
$\mathrm{Ca}^{2+}(\mathrm{mg} / \mathrm{L})$ & 75 & $\mathrm{~N} / \mathrm{D}$ & 3.25 & 3.5 & 2.5 & 4.5 & 4.5 \\
$\mathrm{Cu}(\mathrm{mg} / \mathrm{L})$ & 2 & 0.06 & 1.70 & 1.29 & 1.00 & 0.45 & 1.13 \\
$\mathrm{~F}(\mathrm{mg} / \mathrm{L})$ & 1.5 & $\mathrm{~N} / \mathrm{D}$ & $\mathrm{N} / \mathrm{D}$ & 0.33 & 0.2 & $\mathrm{~N} / \mathrm{D}$ & $\mathrm{N} / \mathrm{D}$ \\
$\mathrm{Fe}(\mathrm{mg} / \mathrm{L})$ & 0.3 & 0.04 & 0.50 & 0.63 & 0.24 & 0.2 & 0.68 \\
$\mathrm{Mg}^{2+}(\mathrm{mg} / \mathrm{L})$ & 125 & 1.83 & 4.5 & 3.1 & 2.67 & 6.25 & 0.35 \\
$\mathrm{NO}_{3}^{-}(\mathrm{mg} / \mathrm{L})$ & 50 & $\mathrm{~N} / \mathrm{D}$ & 0.15 & 0.23 & 0.42 & 0.57 & 0.50 \\
$\mathrm{~K}^{+}(\mathrm{mg} / \mathrm{L})$ & $10-12$ & 1.25 & 3.23 & 2.25 & 1.65 & 1.55 & 0.28 \\
$\mathrm{~Pb}(\mathrm{mg} / \mathrm{L})$ & 0.01 & 0.02 & 0.07 & 0.04 & 0.08 & 0.06 & 0.08 \\
$\mathrm{Zn}(\mathrm{mg} / \mathrm{L})$ & 3 & 0.02 & 0.04 & 0.03 & 0.04 & 0.04 & 0.05 \\
\hline
\end{tabular}

Temp. = temperature; $\mathrm{pH}=$ potential of hydrogen; Turb = turbidity; $\mathrm{EC}=$ electrical conductivity; $\mathrm{TDS}=$ total dissolved solids. $\mathrm{Cl}=\mathrm{Chlorine} ; \mathrm{Al}=\mathrm{Aluminum}$; $\mathrm{NH}_{3}=$ Ammonia; $\mathrm{Ca}=$ Calcium; $\mathrm{Cu}=$ Copper; $\mathrm{F}=$ Fluoride; $\mathrm{Fe}=$ Iron; $\mathrm{Mg}=$ Magnesium; $\mathrm{NO}_{3}{ }^{-}=$Nitrate; $\mathrm{K}=$ Potassium; $\mathrm{Pb}=\mathrm{Lead} ; \mathrm{Zn}=\mathrm{Zinc} ;\left({ }^{\circ} \mathrm{C}\right)=$ degree Celsius; NTU = nephelometric turbidity unit; $\mu \mathrm{S} / \mathrm{cm}=$ micro Siemens per centimeter; $\mathrm{mg} / \mathrm{L}=$ milligrams per liter; $\mathrm{PPM}=$ parts per million; GS = Gondama Stream; DMT = Dry Mill Tailings; GDMT = Gangama Dry Mining Tailings; LDMT $=$ Lanti Dry Mining Tailings; DT $=$ Dredge Tailings; WPT $=$ Wet plant Tailings. There were no guideline values for indicator (s) with blank spaces.

From Table 1, there is significant variation in turbidity values across some of the sampling stations. It was observed that the mean concentration of DMT, GDMT, LDMT, DT, and WPT locations as well as the individual site values, lie above the acceptable WHO limit for turbidity. The LDMT location showed the highest mean turbidity value $43.75 \mathrm{NTU}$ on the whole. It was only samples from GS that showed low turbidity values in line with WHO permissible value. A plausible explanation for low turbidity values in GS apparently could be as a result of serial dilution [14] along the stream given that location GS is far from the tailing areas. In addition, it has been reported that variance in turbidity values along a surface water is strongly associated with stream hydrology and land use pattern [23]. The findings for this indicator is in disagreement with a recent study on ground water quality conducted in the same area where more than $80 \%$ of values were in conformity with WHO value [20]. However, the pattern of turbidity values across locations in the study area of this current study is in agreement with an earlier study on turbidity in different watersheds in New Mexico, USA [23].

For Electrical conductivity (EC), significant variations were noticed across locations but the individual site values, as well as mean concentration values, represent a firm agreement with the guideline standard. It was observed that EC values at the four sites (DMT1 - DMT4) along DMT followed a consistent pattern $(44.6 \mu \mathrm{s} / \mathrm{cm}, 44.6 \mu \mathrm{s} / \mathrm{cm}, 44.5$ $\mu \mathrm{s} / \mathrm{cm}, 44.3 \mu \mathrm{s} / \mathrm{cm}$ ) with DMT recorded the highest mean concentration of $44.5 \mu \mathrm{s} / \mathrm{cm}$ for EC. The findings for EC, however, are in contrast, with a previous study in Namibia that generally reported high electrical conductivity (EC) values even though the design were different [24]. There was a significant difference between mean concentration values of Total Dissolved Solids (TDS) across locations. Again, observably, the four sampling sites in DMT showed the same consistent trend of values $(22.3 \mathrm{ppm}, 22.2 \mathrm{ppm}, 22.2 \mathrm{ppm}$, $22.1 \mathrm{ppm}$ ) for TDS and this pattern is similar to that seen for EC. However, despite the variation amongst locations, both individual sites and mean concentration of locations were lower than the threshold value of the Guideline standard.

From Table 2, there was a high mean concentration of $\mathrm{Pb}$ across locations except in GS where concentration is moderate but the mean concentrations of all sampling locations including GS were above the (WHO 2011) guideline standard of $0.01 \mathrm{mg} / 1$ for water quality. The presence of traces of $\mathrm{Pb}$ in surface water constitute a growing concern [10] because human exposure to high $\mathrm{Pb}$ levels have considerable cumulative effects that would result in fatal health consequences [4]. The average concentration values were high for $\mathrm{Pb}$ obtained in this study but are lower than the peak values obtained in another study in Nigeria [25]. In agreement with our findings for $\mathrm{Pb}$, surface water from Enyigba and Ameka streams, in Ebonyi state, Nigeria; reported values were 70 and 30 times in excess of WHO prescribed value for water quality [26].

Elevated mean concentrations of Fe were noticed in water samples from BDMT, GDMT, and WPT. On the other hand, water samples from GS, LDMT, DT showed low mean concentrations for $\mathrm{Fe}$ and which is in agreement with a recent study in Nigeria [25]. Even at low concentration heavy metals impact negatively on living organisms [4]. It is worthy to note that water samples were collected during the dry season. In view of the aforesaid, an earlier study on stream water of gold mining areas of southwestern Nigeria, have shown that lower mean concentrations were recorded for $\mathrm{Fe}$ especially during the dry seasons. And this could be associated with a sharp decline in entry rate of oxide and clay minerals [15]. However, the study revealed that important increases of iron contents are registered at sites two (2) (i.e. close to the mine tailing discharge) from DMT $(1.2 \mathrm{mg} / \mathrm{L})$, GDMT (1.2 mg/L), and WPT (1.6 mg/L) locations respectively, and are above the acceptable limit of the guideline standard of WHO for iron contents. A similar observation for $\mathrm{Fe}$ was reported for the Toka stream in Gyöngyösoroszi, North Hungary [27]. The high concentration of $\mathrm{Fe}$ at sites 2 (i.e. in the tailings) might also be influenced by the dry season. In support of this, a previous study conducted in Romania by [12] established that during the dry season, the concentration of heavy metals released in aquatic ecosystem increase in the surrounding area of mining waste heaps or tailing dams. The high Fe concentration revealed in this study, is in line [though with lower peak values] with a previous study in Southern Brazil [11].

Water samples tested for $\mathrm{Cu}$ showed values that are within 
the allowable limit by the guideline standard of WHO 2011. Result for $\mathrm{Cu}$ in the study is in contrast to a previous study on surface water in a former mining area of Rudnany, in Slovakia where $\mathrm{Cu}$ values were reported to be above the accepted limit [28]. Further, water samples measured for Aluminum from LDMT, DT, and WPT yield high mean concentration values that are far above the allowable standard for surface water. Emphasis must be drawn to a key observation that samples which were taken at site 2 (i.e. close to the tailings) from GDMT, LDMT, DT, WPT showed very high levels of Al. This study shared similar high Al values with a recent study on water quality in an abandoned mining site in Pahang in Malaysia [9] but the peak values reported in the current study were higher than those obtained in [9].

This study has shown that the metal concentrations of $\mathrm{Cu}$, marked a wide variation between sampling locations and a similar observation was noted in a previous study in Iran [29]. From all sampling locations, it was observed that the concentration trend of trace metals $\mathrm{Zn}, \mathrm{Pb}, \mathrm{Cu}$ decreased at sampling sites downstream which could be associated with distance away from tailings. The same pattern was observed for Calcium. In like manners, decrease in metals and ions content downstream has been reported in an earlier study at Otjihase mine in Namibia [24] and in the Linglong gold mining area, Shandong Province, China [5]. The downstream decrease of some metals has been earlier argued that aqueous dilution lowers contaminant concentrations downstream [30]. Further, the phenomenon of downstream decrease of heavy metals received emphasis in a slightly different study of the Gan River, in China where abundant concentrations of heavy metals in surface water were found only in the upstream and midstream sections and not in the downstream [31]. A study in southern Brazil by [11] concludes that the [high or low] presence of $\mathrm{Zn}, \mathrm{Pb}, \mathrm{Cu}$ and $\mathrm{Ca}$ is largely due to leaching minerals.

Of the six locations investigated, the samples from five locations showed Nitrate levels that is within range of the accepted values except for GS where Nitrate was not detected. Findings for $\mathrm{NO}_{3}^{-}$in this study is in sharp contrast with a similar study in Koira-Joda mining area in India where all water samples were highly contaminated with Nitrate even though their analysis was based on the Indian standard (IS) 10500 (2012) [32]. This observable pattern was different for a recent study in the same area that considered ground water quality which reported elevated levels of nitrate across sampling locations [20]. In the case of fluoride, there was a low detection of this indicator in water samples from GS, DMT, DT, WPT, and at three sampling sites from LDMT. The low detection of fluoride in surface water for $>90 \%$ of the sampling locations is contrary to a previous study reported on the groundwater where about $80 \%$ of samples measured for fluoride showed concentrations that were within the permissible limit [20]. There is paucity of literature on low detection of fluoride in surface water in mining environment but a recent study asserted that divergent fluoride concentrations are because of variations in the local hydrological conditions as well as differences in rocks distribution with readily leachable fluoride [33].

For Ammonia, all locations show low concentration below the regulatory limit of WHO except in one location-GS where this indicator species was not detected. The results showed that the mean value for ammonia is in contrast to a study in Romania despite variance in the study design [12].

\section{Conclusion}

In the current study, surface water samples across streams that drain through mining tailing sites were measured to ascertain the impact of mining activities on the water quality. This study revealed that most of the indicators among the studied sites were relatively higher than those observed at the background site with the exception of $\mathrm{pH}$, turbidity and $\mathrm{Pb}$. It was observed that $\mathrm{pH}$ and $\mathrm{Pb}$ were well above the acceptable limit at the background site contrary to the other physical and chemical indicators among the sites. Elevated levels of $\mathrm{Zn}, \mathrm{Pb}$ and $\mathrm{Cu}$ were recorded at all of the tailing points but decrease concentration was observed downstream. Turbidity, $\mathrm{pH}, \mathrm{Pb}, \mathrm{Fe}$, and $\mathrm{Al}$ were observed to be a public health concern for local inhabitants considering WHO guideline values. Even though most indicators were in agreement with water potability, this study has shown that tailings due to mining operations impacts nearby streams negatively and could have general implications for surrounding water bodies. In spite of the continual efforts by Sierra Rutile Mining Company Limited to improve on their environmental performance in relations to improve water quality, our finding has pointed to the fact that more environmental management actions should be strengthened.

\section{References}

[1] World Health Organization (2011) Guidelines for drinkingwater quality. $4^{\text {th }}$ ed. ISBN 9789241548151.

[2] World Health Organization (WHO) and the United Nations Children's Fund (UNICEF) (2017) Progress on Drinking Water, Sanitation and Hygiene: 2017 Update and SDG Baselines. Geneva. Licence: CC BY-NC-SA 3.0 IGO.

[3] Md. Khan, H. R. Seddique, A. A. Rahman, A. Shimizu, Y. (2017) Heavy Metals Contamination Assessment of Water and Soils in and Around Barapukuria Coal Mine Area, Bangladesh. American Journal of Environmental Protection, 6, 80-86.

[4] Sankhla, M. S. Kumari, M. Nandan, M. Kumar, R. Agrawal, P. (2016) Heavy Metals Contamination in Water and their Hazardous Effect on Human Health-A Review. International Journal of Current Microbiology and Applied Sciences, 5, 759-766.

[5] Ning L. Liyuan Y. Jirui D. Xugui P. (2011) Heavy Metal Pollution in Surface Water of Linglong Gold Mining Area, China. 2011 3rd International Conference on Environmental Science and Information Application Technology. Procedia Environmental Sciences, 10, 914-917.

[6] Atibu, E. K. Devarajan, N. Thevenon, F. Mwanamoki, P. M. Tshibanda, J. B. Mpiana, P. T. Prabakar, K. Mubedi, J. I. Wildi, W. Poté, J. (2013) Concentration of metals in surface water and sediment of Luilu and Musonoie Rivers, KolweziKatanga, Democratic Republic of Congo. Applied Geochemistry, 39, 26-32. 
[7] Book, F. (2014) Risk assessment of mining effluents in surface water downstream the sulphide ore mine Aitik, northern Sweden. Master thesis in Ecotoxicology, Master's Program, 120 hec. Department of Biology and Environmental Science, University of Gothenburg. P 7.

[8] Ashraf, M. A. Maah, M. J. Yusoff, I. Ghararibreza, M. (2012) Speciation of heavy metals in the surface waters of a former tin mining catchment. Chemical Speciation and Bioavailability, 24, (1).

[9] Madzin, Z. Kusin, F. M. Yusof, F. M. Muhammad, S. N. (2016) Assessment of Water Quality Index and Heavy Metal Contamination in Active and Abandoned Iron Ore Mining Sites in Pahang, Malaysia. MATEC Web of Conferences 103, 05010 (2017) DOI: 10.1051/matecconf $/ 20171030$ ISCEE 2016.

[10] Smical, I. Muntean, A. Nour, E. (2015) Research on the Surface Water Quality in Mining Influenced Area in NorthWestern part of Romania. Geographica Pannonica, 19, 20-30.

[11] Campaner, V. P. Luiz-silva, W. Machado, W. (2014) Geochemistry of acid mine drainage from a coal mining area and processes controlling metal attenuation in stream waters, southern Brazil. Annals of the Brazilian Academy of Sciences. http://dx.doi.org/10.1590/0001-37652014113712.

[12] Modoi, O. C. Roba, C. Török, Z. Ozunu, A. (2014) Environmental risks due to heavy metal pollution of Water resulted from mining wastes in Nw Romania. Environmental Engineering and Management Journal, 13, 2325-2336.

[13] Moschini-Carlos, V. Pompêo, M. L. M. Lobo, F. D. L. Meirelles, S. T. (2011) Impact of coal mining on water quality of three artificial lakes in Morozini River Basin (Treviso, Santa Catarina State, Brazil). Acta Limnologica Brasiliensia, 23, 271-281.

[14] Rakotondrabe, F. Ngoupayou, J. R. N. Mfonka, Z. Rasolomanana, E. H. Abolo, A. J. N. Asone, B. L. Ako, A. A. Rakotondrabe, M. H. (2017) Assessment of Surface Water Quality of Betare-Oya Gold Mining Area (East-Cameroon). Journal of Water Resource and Protection, 9, 960- 984.

[15] Wasiu, M. O. Ayodele, O. E. Ayodele, T. I. Oluremi, O. I. Temitope, O. K. Temitope, F. O. (2016) Heavy metal contamination in stream water and sediments of gold mining areas of South Western Nigeria. African Journal of Environmental Science and Technology, 10, 150-161.

[16] Hadzi, G. Y. Essumang, D. K. Adjei, J. K. (2015) Distribution and Risk Assessment of Heavy Metals in Surface Water from Pristine Environments and Major Mining Areas in Ghana. Journal of Health \& Pollution, 5, 86-99.

[17] Mansaray, A. S. Borsuah, J. F. Gogra, A. B. Fofana, B. P. Koroma, B. M. (2017) The Safety of Water Supplied at Njala University, Njala Campus. Natural Resources, 8, 81-93.

[18] Nwamaka, I. K. Akudo, A. D. (2014) Assessment of groundwater quality in wells within the Bombali District, Sierra Leone. Animal Research International, 11, 1905-1916.

[19] Jimmy, D. H. Sundufu, A. J. Malanoski, A. P. Jacobsen, K. H. Ansumana, R. Leski, T. A. Bangura, U. Bockarie, A. S. Tejan, E. Lin, B. Stenger, D. A. (2012) Water Quality associated Public Health Risk in Bo, Sierra Leone. Environmental Monitoring and Assessment, 185, 241-251.

[20] Massally, R.-E. M. Sheriff, A. B. Kaitibi, D. Abu, A. Barrie,
M. Taylor, E. T. (2017) Comprehensive Assessment of Groundwater Quality around a Major Mining Company in Southern Sierra Leone. Journal of Water Resource and Protection, 9, 601-613.

[21] Ashraf, M. A. Maah, M. J. Yusoff, I. B. (2010) Study of Water Quality and Heavy Metals in Soil \& Water of Ex-Mining Area Bestari Jaya, Peninsular Malaysia. International Journal of Basic \& Applied Sciences, 10, 03.

[22] Ochieng, G. M. Seanego, E. S. Nkwonta, O. I. (2010) Impacts of mining on water resources in South Africa: A review. Scientific Research and Essays, 5, 3351-3357.

[23] Huey G. M. Meyer M. L. (2010) Turbidity as an Indicator of Water Quality in Diverse Watersheds of the Upper Pecos River Basin. Water, 2, 273-284.

[24] Mufenda, M. Ellmie R. (2009) Characterization of contamination of stream sediments and surface water at Otjihase mine, Namibia. Communs. Geol. Survey. Namibia, $14,41-55$

[25] Sanusi K. A. Hassan M. S. Abbas M. A. Kura A. M. (2017) Assessment of heavy metals contamination of soil and water around abandoned $\mathrm{Pb}-\mathrm{Zn}$ mines in Yelu, Alkaleri Local Government Area of Bauchi State, Nigeria. International Research Journal of Public and Environmental Health, 14, 7277.

[26] Nnabo, P. N. (2015) Assessment of Heavy Metal Contamination Of Water Sources From Enyigba $\mathrm{Pb}-\mathrm{Zn}$ District, South Eastern Nigeria. International journal of Scientific \& Technology Research, 4, 187-197.

[27] Kovács, E. Tamás, J. Frančišković-Bilinski, S. Omanović, D. Bilinski, H. Ivanka Pižeta, I. (2012) Geochemical study of surface water and sediment at the abandoned $\mathrm{Pb}-\mathrm{Zn}$ mining site at Gyöngyösoroszi, Hungary. Fresenius Environmental Bulletin, 21, 5a. 2012.

[28] Angelovičová L. Fazekašová D. (2014) Contamination of the soil and water environment by heavy metals in the former mining area of Rudňany (Slovakia). Soil \& Water Res, 9, 18-24.

[29] Sobhanardakania, S. Yarib, A. R. Taghavic, L. Tayebid, L. (2016) Water Quality Pollution Indices to Assess the Heavy Metal Contamination, Case Study: Groundwater Resources of Asadabad Plain in 2012. Arch Hyg Sci, 5, 221-228.

[30] Kossoff, D. Dubbin, W. E. Alfredsson, M. Edwards, S. J. Macklin, M. G. Hudson-Edwards, K. A. (2014) Mine tailings dams: Characteristics, failure, environmental impacts, and remediation. Applied Geochemistry 51, 229-245.

[31] Hua, Z. Yinghui, J. Tao, Y. Min, W. Guangxun S. Mingjun, D. (2016) Heavy Metal Concentrations and Risk Assessment of Sediments and Surface Water of the Gan River, China. Pol. J. Environ. Stud,. 25, 1529-1540.

[32] Gleekia, A. M. G. D. Sahu, H. B. (2016) Impacts of iron ore mining on water quality-a comparative study of India and Liberia. Conference paper 6th ASIAN MINING CONGRESS 23-26 February 2016, Kolkata, India. The Mining Geological and Metallurgical Institute of India (MGMI).

[33] O’Mullane, D. M. Baez, R. J. Jones, S. Lennon, M. A. P. E. Petersen, P. E. Rugg-Gunn, A. J. H. Whelton, H. Whitford, G. M. (2016) Fluoride and Oral Health. Community Dental Health 33, 69-99. 